This item was submitted to Loughborough's Research Repository by the author.

Items in Figshare are protected by copyright, with all rights reserved, unless otherwise indicated.

\title{
Dancing to a resistant imaginary: reconfiguring female (a)sexualities through Zorbitality
}

\section{PLEASE CITE THE PUBLISHED VERSION}

https://doi.org/10.1080/14780887.2018.1456588

\section{PUBLISHER}

(C) Taylor \& Francis

\section{VERSION}

AM (Accepted Manuscript)

\section{PUBLISHER STATEMENT}

This is an Accepted Manuscript of an article published by Taylor \& Francis in Qualitative Research in Psychology on 09 Apr 2018, available online: https://doi.org/10.1080/14780887.2018.1456588

\section{LICENCE}

CC BY-NC-ND 4.0

\section{REPOSITORY RECORD}

Sadlier, Aoife. 2018. "Dancing to a Resistant Imaginary: Reconfiguring Female (a)sexualities Through Zorbitality". Loughborough University. https://hdl.handle.net/2134/32585. 
Title: Dancing to a resistant Imaginary: Reconfiguring female (a)sexualities through Zorbitality

Author's name: Dr Aoife Sadlier

Institutional affiliation (current): School of Sport, Exercise and Health Sciences, Loughborough University, LE11 3TU, United Kingdom.

Correspondence email: A.C.Sadlier@lboro.ac.uk

This work formed part of a PhD that was obtained in the Department of Culture, Media and Creative Industries, King's College London, in April 2017. This research was generously funded by the Economic and Social Research Council of Great Britain (ESRC) from September 2013 to March 2017. 


\section{Abstract}

In the twenty-first century, asexuality has become synonymous with sexual orientation, being described as a 'lack' of sexual attraction. At this juncture, a study of female (a)sexualities is long overdue. Firstly, very little has been written on the topic. Secondly, with the rise of a postfeminist culture, women are often represented as desiring their own objectification, whilst the narratives of asexual-identified women are reduced to static narratives of frigidity or spiritual devotion. In response, this paper develops the concept of Zorbitality. Zorbitality is a resistant imaginary, which seeks to reconfigure female (a)sexualities through collective ecstatic motion. It harnesses the historical transformation and cultural hybridity of Afro-diasporic rhythms, to interrogate the Western thought systems that constrain women's ecstatic movement. The paper draws on two methodologies: Deleuzian feminist cartographies and collective biography. These methodologies together speak to a posthuman concern with reaching an enhanced sense of the collective, through a focus on the affective intensity of each moment. Two dance narratives will frame the analysis: Stravinsky's (1913) ballet, The Rite of Spring, where a sacrificial 'virgin' dances herself to death, and West African Yoruba dance, characterised by solo dance within a collective. These narratives will interweave in the memory of a woman called Martha, in which her solo dance within a collective evokes the uncreolised African body and enables her to experience an ethical opening to human and non-human others.

Keywords: Zorbitality, Asexuality, female (a)sexualities, Deleuzian feminist cartographies, collective biography, Afro-diasporic dance, collective ecstasy, Rite of Spring. 
Title: Dancing to a resistant imaginary: Reconfiguring female (a)sexualities through Zorbitality

\section{Introduction}

These moments and movements are not towards the transformation of ourselves into new subjects in linear time. Rather, the transformation lies in a particular form of attention to the remembered moment, an attention that makes the subject's vulnerability to discursive power starkly visible while also making visible the constitutive powers of the subject-in-process (Davies and Gannon, 2006, p. x)

This paper extends an invitation to dance around the patriarchal structures that have historically constrained female ecstatic movement. Throughout the following pages, female (a)sexualities ${ }^{1}$ and indeed the category of 'woman' will be viewed as dancing processes, which we can continually deconstruct and reconstruct in light of our collective dance. Furthermore, as I will continually highlight, the internalisation of a collective ecstatic spirit can act as a resistant imaginary for women, whilst building a more ethical society for both human and non-human beings. In resonance with Cixous and Clément (1986) theory of the feminine libidinal economy, ${ }^{2}$ I seek to argue that the female body in motion can thwart patriarchal structures. Yet, referencing Stacey's (1999) work, I wish to argue for a 'feminine specificity without falling into the trap of biological essentialism' (Stacey, 1999, p. 263). Ultimately, I wish to highlight how the ecstatically moving female body is a powerful expression of vital life, and should be central to a reconceptualisation of female (a)sexualities.

In the twenty-first century, 'asexuality' has become synonymous with sexual orientation, being described by psychologists and the asexual community as a 'lack' of sexual attraction (Bogaert, 2004, p. 279; AVEN, 2017). This definition is 
problematic, as it erodes individual idiosyncrasies, assumes that everybody is sexual and that sexuality is immutable. Furthermore, it denies the fact that sexual orientation categories are products of patriarchy and capitalism.

At this juncture, a study of female (a)sexualities is long overdue, since the paradigm that sees women as pure until penetrated by men and sexual intercourse as defined through heterosexual coitus alone has dominated the landscape of sexual politics for millennia. Rich (1980) referred to this phenomenon as 'compulsory heterosexuality.' Yet, furthermore, 'compulsory sexuality,' which refers to 'the pervasive cultural assumption - set into relief by the emergence of asexuality and popular responses to it - that everybody is defined by some kind of sexual attraction' (Emens, 2014, p. 306) has come to act as a double form of oppression. It is through these prisms that thirteenthcentury nuns who chose a spiritual life came to be seen as fighting a desire for sex rather than engaging in a powerful orientation towards chastity (Karras, 2005), and certain radical feminists of the 1960s, who advocated non-sexual relationships with other women, came to be chided for desexualising lesbianism (see Hollibaugh and Moraga, 1981). Myra T. Johnson's (1977) chapter was perhaps the only work that referenced these deficits. She highlighted the dangers of reducing asexual-identified and autoerotic women ${ }^{3}$ to symbols of spiritual devotion or political consciousness at the absence of examining their lived realities, a concern that still resonates in the twenty-first century.

As Gill and Scharff (2011) assert, with the rise of a postfeminist sensibility whereby women are represented as desiring their own sexual objectification, the 
possibility of new female subjectivities is being limited for all women and the narratives of asexual-identified women are in danger of being lost. Therefore, a study of female (a)sexualities is particularly relevant to the twenty-first century. This paper focuses on women, because as Young (2005 [1980]) demonstrated, female bodily agency is constrained within heteronormative spaces in the Western world. Although heteronormative culture is undoubtedly limiting for men, its effects are not as marked as for women, due to deeply ingrained patriarchal structures. Yet, at the same time the category of woman should be viewed as dancing (Riley, 1987), so that biological determinism does not hold it in place.

In response to these concerns, this paper draws on and extends a Deleuzian feminist perspective, especially Braidotti's $(2006,2012,2013)$ work on nomadic subjectivity. Braidotti's thought challenges the limitations of humanist discourses, namely the viewpoint that humans have a unitary subjectivity and can be liberated through identity categories. Rather it espouses posthumanism, as the ability to manifest oneself through different identities and to ethically open oneself to human and non-human others (Braidotti, 2013). This perspective serves to highlight how an inclusive society may be built through searching for 'a world in common' (Mbembe, 2017, p. 176), where we harness cultural hybridity as a means of collectively enjoying the affective intensity of each moment. As Massumi (2004, p. xvii) notes in his introduction to Deleuze and Guattari's (2004 [1980]) A Thousand Plateaus, affect is 'a prepersonal intensity corresponding to the passage from an experiential state of the body to another and implying an augmentation or diminution in that body's capacity to 
act.' Therefore, according to a Deleuzian conception (Deleuze and Guattari, 2004 [1980]), affect is grounded in corporeality, mobility and the interaction between bodies. Affective intensity in this context refers to 'a continuous, self-vibrating region of intensities whose development avoids any orientation toward a culmination point or external end' (ibid, p. 24). Dance, as a 'sign for life' (Fraleigh, 1987, p. xvii) could be a valuable way of setting this process in motion. Indeed, collective ecstatic motion could act as a powerful new framing for female (a)sexualities, as encapsulated in my concept of Zorbitality.

\section{1 - Defining Zorbitality}

Zorbitality is an emergent concept $\mathrm{t}^{4}$ that I have devised, which seeks to transcend the societal structures that constrain women's ecstatic movement. It takes the Caribbean and by extension Latin America as a central locus for its theorisations. ${ }^{5}$ This is because the history of the Caribbean challenges the unitary notion of a subject, as it is characterised by transformation and the merging of different cultures. As Hall (2001[1995], p. 282) notes: '... if the search for identity always involves a search for origins, it is impossible to locate in the Caribbean an origin for its peoples.' Furthermore, as Benítez-Rojo (1996) highlights, the difficulty in studying the Caribbean is its lack of historical continuity. Its various European languages, brought from the time of the conquests, its African and Asian heritages, are full of time shifts and indefinite interactions. However, this very lack has created a sense of rhythmic vitality, characterised by 'processes, dynamics, and rhythms that show themselves within the marginal, the regional, the incoherent, the heterogeneous, or, if you like, the unpredictable that coexists with us in our everyday world' (ibid, p. 3). The 
Caribbean represents endless flux, sketching in 'an "other" shape that keeps changing' (ibid). Finally, Caribbean history exists as 'one of the main strands in the history of capitalism' (ibid, p. 5), where from the fifteenth century Western colonisers set their anchors and began to capitalise on the economies of the local people. From this colonial encounter, 'Latin America' emerged as an 'idea' (Mignolo,2005, pp. x-xi).

As Mbembe (2002) notes, the colonisers involved African people in their own subjection, since African middlemen could make profit from the capturing and selling of slaves, with the promise of 'upward mobility' (Mbembe, 2002, p. 263). It is in this system of colonial exchange that female (a)sexualities also have their roots. Asexuality is constructed as a 'lack' in the twenty-first century because it does not support the capitalist economy. Yet, in a similar manner to Caribbean identities, this sense of 'lack' could be seen as an internalisation of a coloniser's discourse (Hall 2001 [1995]). Furthermore, it is the colonisers' oppression of collective ecstatic movement rites that this paper acknowledges and subverts, by drawing on collective ecstasy as its tool of resistance.

Zorbitality is coined through a number of words, each of which expresses movement in a different way: Zumba, Zorb, Orbit and Vitality. Firstly, Zorbitality draws on the collective joy of Zumba ${ }^{\circledR}$ Fitness, a twenty-first century global Latin dance fitness phenomenon (Kabir, 2015a), as a central example. ${ }^{6}$ However, Zorbitality can be accessed through other collective movement rites. Zumba®’s vital life parodies the capitalist system from which it emerged, since its sense of collective joy may be integrated into everyday life. Furthermore, Zumba ${ }^{\circledR}$ 
highlights the eternal transformation of Afro-diasporic rhythms and opens up new relational possibilities through the specific configuration of solo within a collective.

The second word, 'zorb,' is an object that enables a new way of moving. It is a plastic circle, in which one stands, walks and directs movement. One is cocooned and safe, within one's own kinetic sphere. On a micro level, the word 'zorb' contains 'orb,' a circular ball of light that is often seen in digital photography, sometimes with trails that suggest motion and a transferral of energy. This resonates with Deleuze and Guattari's (2004 [1980]) concept of the rhizome, which Glissant (1997, p. 11) describes as:

an enmeshed root system, a network spreading either in the ground or in the air, with no predatory rootstock taking over permanently. The notion of the rhizome maintains, therefore, the idea of rootedness but challenges that of a totalitarian root.

The third word, 'orbit,' suggests movement in a circular rather than linear way. Perhaps, it best suggests 'a circularity with volume' (ibid, p. 32), which looks beyond the 'arrowlike nomadism' (ibid, p. 18) of Western colonisers, to the power of 'circular nomadism' (ibid). In circular nomadism, 'uprooting can work towards identity, and exile can be seen as beneficial, when these are experienced as a search for the Other... rather than as an expansion of territory... (ibid)' In its basic form, Zorbitality may be reached in the process of physically embodied collective ecstatic motion. Yet, others do not need to be physically present for Zorbitality to be accessed. 
Contained within the final word, 'vitality,' is the vital energy of embodied experience, as well as the last letters of the word 'digital.' Zorbitality disrupts the linearity of neoliberal regimes and the capitalist commodification of human desires, emphasising experimentation and collective joy. Thus, Zorbitality extends Braidotti's (2006, p. 4) theory of nomadic subjectivity as 'a nonessentialist brand of vitalism,' by showing how this vitalism may be encountered in a collective movement experience, which can be integrated into everyday life.

Zorbitality engages with biopolitics: the interaction between the biological and the discursive as manifested in processes of health, pleasure and sexuality, thus 'exposing the opening of the body and of life itself, to its own historicity and indeterminacy' (Giorgi, 2002, p. 35). Vitality in this context embodies movement and transformation. Most significantly, as I will emphasise throughout this paper, Zorbitality answers and extends Braidotti's (2006, p. 33) call for a 'sustainable nomadic ethics.' This 'implies a new way of combining self-interests with the well-being of an enlarged sense of community, which includes one's territorial or environmental interconnections' (ibid, p. 35). A sustainable nomadic ethics takes zoe, 'the endless vitality of life as continuous becoming' (ibid, p. 41) as its starting point. In response, Zorbitality offers a resistant imaginary, which is reached through a threefold process, from vulnerability to inner ecstasy and collective ecstatic motion. This process maps a journey from constraints within patriarchal structures, to the creative transgression of these structures in everyday life, to engagement in collective movement. Yet, Zorbitality reaches its strongest manifestation through the internalisation of a 
collective spirit, which may be drawn upon as a resistant imaginary in times of vulnerability.

\section{2 - Methodology}

The paper draws on two methodologies: Deleuzian feminist cartographies (Braidotti, 2012) and collective biography (Davies and Gannon, 2006). Each of these is navigated through a dance narrative. My first methodology, cartographies, does not draw on a genealogy of linear transformation, as in Foucault's (1978 [1976]) work, but rather looks to Deleuze and Guattari's (2004 [1980]) rhizomatic writing, characterised by various firing points and overlapping genealogies. Most pertinently, this methodology draws on Braidotti's (2012, p. 271) concept of cartography, which refers to 'a politically informed map of one's historical and social locations, enabling the analysis of situated formations of power and hence the elaboration of adequate forms of resistance.' I draw on this methodology as a means of situating asexuality within sociohistorical debates within Western culture, drawing on the tradition of Western ballet as a locus for my discussions, and using this as a springboard for developing a narrative of resistance. I describe and analyse the sacrificial dance of the 'Chosen One' in Stravinsky's seminal (1913) ballet, The Rite of Spring, to illustrate my arguments. In this work, a young 'virgin' is chosen as a sacrificial victim by the male elders of a pagan community and dances herself to death. In this Western dance narrative, asexuality is thus viewed negatively and is associated with a static death dance. I will contextualise my analysis through Freud's (1954 [1897]) theorisations of the hysteric woman, which highlighted a fear of women's transgressive movement, and a brief history of the Western 
feminist movement, which demonstrates women's failure to unite in a collective dance that could hold a broader range of female (a)sexualities. I will subsequently highlight how collective ecstasy was quashed through Western colonisation of the 'New' World. However, in the remainder of the paper, I seek to challenge the death of the Chosen One, and to re-enact it as a dance of agency.

My second methodology is collective biography, which is defined as 'a coproduced, intertwined, reflexive biography, working with memory and storytelling' (Denzin, 2014, p. 23). Davies and Gannon (2006) developed this method by extending Frigga Haug's (1987) memory work. Haug was inspired by Marxism, and drew on women's stories as a means of examining the social structures underpinning gender inequality. She theorised from experience and made the researcher an intricate part of the research process. She highlighted how a major obstacle in making sense of our experience lies in viewing our lives as linear biographies (Stephenson and Kippax, 2008). Collective biography extends Haug's work, by entirely challenging the view of the unitary subject. It addresses the concerns of this paper, as it foregrounds the discourses that are formative in women's recognition of themselves as sexual subjects. Equally, it highlights how our narratives are inter-related, whilst focusing on the embodied details of memories.

Braidotti's (2006) concept of nomadic remembering, which draws on Deleuze and Guattari's (2004 [1980]) majority and minority memory, will be key to my theorisations. As Braidotti (2006, p. 168) notes: 'When you remember in the intensive or minority-mode, you open up spaces of movement and of 
deterritorialization which actualize virtual possibilities which had been frozen in the image of the past.' In this vision, memory is viewed as a creative process, which celebrates the positivity of difference and eschews the psychoanalytic focus on a repressed past. Trauma creates a generative possibility. The self can be reinvented in a discontinuous way, which challenges the patriarchal order: 'Remembering in this nomadic mode is the active reinvention of a self that is joyfully discontinuous, as opposed to being mournfully consistent, as programmed by phallogocentric culture' (ibid, p. 169). Ultimately, by drawing on this conception of memory, I seek to highlight the temporal aspects of female (a)sexualities, offsetting the sociohistorical landscape of the cartographies section.

At the beginning of the collective biography section, I introduce the narrative of the African American anthropologist and dancer, Katherine Dunham (19092006), who developed her own choreographic empire based around the memory of the black diaspora via her fieldwork experiences in the Francophone Caribbean, in the twentieth century. Significantly, Dunham's initiation into the vaudun danced religion enabled her transformation. I discuss her narrative in tandem with that of Martha, a 34-year-old white middle-class able-bodied woman from Ireland, who participated in collective biography work, as part of my $\mathrm{PhD}$ research in female (a)sexualities. I do so in order to highlight the posthuman possibilities of collective movement.

Martha was recruited from an online gender and sexuality forum, and was told that the study was exploring 'women's memories of sexuality and becoming 
women.' Two workshops were held with each group, which explored four specific memories: (i) my first memory of being recognised as an adult woman, (ii) a memory of ambivalence (from any part of my life) related to being recognised as female, (iii) a memory where I stayed silent when I longed to speak up against a threat to my gender/sexuality or a memory where I spoke up against a threat to my gender/sexuality and (iv) a memory where I felt completely free in my body. This paper relates to the fourth of these memories .

I will focus on a particular memory, where Martha danced, naked and vulnerable in front of others, which was key to her personal transformation. I argue that her memory evokes the memory of an uncreolised African body, through the specific configuration of solo dance within a collective, which is popular in the collective dances of the Yoruba people of Southwestern Nigeria, Benin and Togo. I draw on Glissant's (1997) definition of creolisation, which highlights the interpenetration of various cultural elements, and the symbolic value of this exchange.

'Uncreolised' here refers to the vital life of the body; a body free of classification, with no specific origins. This speaks to Butchart's (1998) genealogy of the black African body from the Renaissance to the 1990s, which he engaged with 'to overcome the difficulties of the myth of origin in which a particular time is reified and particular understandings of experiences, mentality and subjectivity are essentialized' (Macleod and Bhattia, 2008, p. 585). He thus sought to show that there is no original black African body distorted by the 'classificatory gaze' of Western colonisers (Butchart, 1998, p. 51). In this way, collective ecstatic motion can be understood as an alternative centralising force, where transformation is seen as key to an enhanced human subjectivity. ${ }^{7}$ In this vision, 
collective ecstatic motion can be internalised as a resistant imaginary, which sustains one in moments of vulnerability. Through her dance of vulnerability, Martha challenges the image of the woman dancing herself to death in Stravinsky's Rite, and reconfigures asexuality as a dance of agency. Indeed, as I will argue through my discussion of Mbembe's (2002) work on African modes of self-writing, her dance highlights the possibilities of a resistant 'self-styling.' This enables us to break down the limitations of the unitary subject and to find our own personal way of moving within a collective, whilst reaching a union with a broader cosmos.

Within this section, I situate myself as a white middle-class Irish woman, who previously identified with asexuality but who subsequently chose not to identify with labels, through a gradual realisation that asexuality is a construction of patriarchy and capitalism, and through my own collective movement practices. As a teacher of the global Latin dance fitness programme, Zumba ${ }^{\circledR}$ Fitness, I have reflected on my role as a European researcher of the African diaspora and on the commodification of the Afro-diasporic rhythms via the processes of capitalism and globalisation. I am therefore aware of accusations of 'playing Indian' (Deloria, 1998, p. 7) that could be levelled against my work, and seek to challenge these through appealing to an enhanced sense of the collective, via a Deleuzian feminist framework.

The structure of this paper could be said to be Zorbital, as it weaves two contrasting methodologies and dance narratives. This approach resonates with recent developments in Western social science methodology, which highlight the 
role of the imagination in the process of remembering (Keightley and Pickering, 2013) and utopia as method (Levitas, 2013). Furthermore, it evokes the multifaceted lineage of Latin American literature, in particular the genre of marvellous realism, which emerged from Carpentier's (1995 [1949]) work. ${ }^{8}$ Magical realism seeks to transcend social, geographical and political boundaries, by making magic and transformation central to the process of writing. As Parkinson Zamora and Faris (1995) note, as a fictional genre, it is particularly useful for women's writing and postcolonial writing, since it offers a strategy for reworking various colonisations. In essence, alternative futures evoked by the imagination enable a rewriting of personal memories and historical events. With this thought in mind, I will now turn to my first methodology: cartographies.

\section{Cartographies}

\subsection{Stravinsky's Rite of Spring}

Stravinsky's (1913) ballet, The Rite of Spring (Le Sacre du Printemps), premiered at the Théâtre des Champs Elysées, Paris, on 29 May 1913. Diaghilev's Ballets Russes performed the work, with costumes and scenery by Roerich, and choreography by Nijinsky. In the original performance, the male elders of an imagined Russian pagan community chose a girl ('The Chosen One') as a sacrificial offering, watching her '... dance herself to death. They were sacrificing her to propitiate the god of spring' (Stravinsky, 1975 [1935], p. 31). ${ }^{9}$ Garafola (1998, p. 72) mentions ancient Aztec sacrificial rituals as a possible influence for Stravinsky's rite, as well as the dominant trend of seeing women as primitive beings at that time (see Freud, 2001 [1905]). As Berg (1988, p. 50) notes, the girl is not chosen specifically by her community, but rather by nature, a force beyond 
her control. Yet, the activities leading to this death dance stratify gender roles in such a way that it will always be a girl that is chosen. She is a vulnerable subject.

The work is written in two parts. In the first, an old woman enters and begins to tell the future. ${ }^{10}$ The rival tribes play games, ${ }^{11}$ and then the girls dance a circle dance..$^{12}$ The rival tribes dance to celebrate the arrival of spring,,$^{13}$ before an ancient sage kisses the earth. ${ }^{14}$ This part ends in a danced orgy, where all the dancers become one with the earth. ${ }^{15}$ In the second part, the young maiden is chosen from a mystic circle, after she trips. ${ }^{16}$ The other women surround her, teaching the Chosen One her death dance, while she remains frozen on the spot. ${ }^{17}$ The girls then evoke the ancestors and the Chosen One attempts to flee the circle. ${ }^{18}$ Subsequently, the Chosen One is groomed for the sacrifice by the male elders ${ }^{19}$ and ultimately 'dances herself to death, thus metaphorically marrying Yarilo, the sun god, ruler of spring' (Banes, 1998, p. 102). The elders lift her to the skies. ${ }^{20}$

As Hill (2000, p. vii) remarks of Stravinsky's Rite, it was a masterpiece of the twentieth century, which broke totally with the past of Classical music, whilst remaining deeply 'rooted in tradition.' Its combination of folk melodies, atonal writing, accents, and polyrhythms ${ }^{21}$ created a sense of freedom and vitality, which offers some groundwork for Zorbitality as a twenty-first century conceptual framework grounded in transformative rhythms. The Rite caused quite a riot at the time, as its dancing style, which was perceived as primitive, disturbed many, as did its dissonant music. Perhaps even more of a challenge though, as noted by Banes (1998, p. 105), was the way the work connected 
sexuality and sexual reproduction with community. In its original choreographic context, the evocation of a pagan culture required a dance language that went far beyond what had been previously prescribed within Classical ballet. Instead, the movements were angular and feet were turned in, which in Hodson's (1996, p. xix) words 'suggested vulnerability but also autonomy.'

The work offers Zorbital possibilities. Firstly, it creates a gender-neutral choreographic language, where collective movement is the driving force and dyadic formations do not feature prominently (Banes, 1998). Secondly, the work's rhythmic ingenuity has been continually renewed and experimented with by various choreographers, and thus defies one univocal representation. This sense of experimentation has a genealogical connection with the Caribbean as a site of hybridity (Hall, 2001 [1995]) and Zorbitality as a libidinal economy grounded in transformation, movement and collective ecstasy. Yet, I argue that no interpretation has succeeded in challenging the patriarchal nature of the work itself. ${ }^{22}$

In Sexes and Genealogies (1993 [1987], p. 188), Irigaray describes patriarchy as ‘a society of intermale bonding, which respects only the genealogy of the sons and the fathers and the competition between brothers.' In the process, women's genealogies are subordinated to men's. This is evidenced in some female choreographers' interpretations of the Rite, which have exhibited a sense of internalised patriarchy. For instance, Martha Graham drew on her travels through New Mexico in her 1983 version of Stravinsky's Rite (see Berg, 1988, pp. 141-151). Yet, her interpretation was misogynist, provoking Goldberg (1986, p. 
17) to assert that it 'was essentially a well-dressed rape onstage...' I challenge Graham's vision by naming the character of my alternative sacrificial dance 'Martha,' who we will meet in the collective biography section. However, as part of the ebbs and flows of this cartography, I will now take a step back for a moment and examine the archaic routes of the stifling of women's ecstatic movement within Western culture. As in Stravinsky's Rite, this was set in motion by men's fears of women's bodily movement and by women's failure to unite in a collective dance. While I will situate this work primarily within the contexts of the nineteenth and twentieth centuries, via Freud's (1954 [1897]) theorisation of female hysteria and the shifting tides of the feminist movement from the late nineteenth century onwards, I wish to highlight the genealogical construction of the female 'asexual' across time.

Freud's (1954 [1897]) theorisations of female hysteria and frigidity sought to classify women who were 'averse' to sexual intercourse. As well as seeing this as a sign of psychological dysfunction, Freud also associated it with the erratic movement of women's bodies, which needed to be controlled. A genealogical link exists between the nineteenth-century frigid woman and the diabolic witch, who was hunted during the medieval period, both of whom can be seen as cultural referents of the female 'asexual.' The fact that these women could manifest a sense of festival within their own bodies was seen as a threat, connected with the image of the abject mother (de Oliveira and Still, 1999, p. 103). More specifically, each of these figures was punished, due to men's fears of their eternal movement and transformation, which goes far back in the history of Western culture. For instance, in the second century, Galen put forward the 
theory of the wandering womb, which viewed it as 'altogether erratic... like an animal within an animal' (in Lefkowitz and Fant, 2005, p. 248). This perspective was carried forward Kramer and Sprenger's (1968 [1487], p. 63) Malleus Maleficarum, a fifteenth-century handbook for witchcraft, which viewed the witch's transvection as threatening: 'And among their chief operations are being bodily transported from place to place, and to practise carnal connexion with Incubus devils...' In a letter to Fliess from 24 January 1897, in which he also stated that he had ordered a copy of the Malleus, Freud postulated that the hysterical woman's movements preserve 'the remnants of a primitive sexual cult, which in the Semitic east may once have been a religion' (Freud, 1954 [1897], p. 189), and asserted that he understood 'the stern therapy of the witches' judges' (ibid). These thoughts serve to highlight that the root of the female asexual as sacrificial subject - the constraint of women's collective ecstatic movement need to be challenged. Furthermore, these roots are tied up with a profound ethnocentricism, which needs to be interrogated via a focus on cultural hybridity and affective intensity.

It is not only men's fear of women's ecstatic movement, however, that constructs the female 'asexual' as a static subject. It is also women's failure to unite in a collective dance, which could hold a broader range of female (a)sexualities. The history of Western feminism demonstrates a constant return to a problematic liberation/repression debate, which began during the first wave of the late nineteenth century and reached its epitome in the sexual 'revolution' of the 1960s and 70s. As Milks (2014) notes, the liberal feminist movement was overtly sex-positive and largely exclusionary of asexual-identified women. Often 
forgotten in the history of the second wave is the radical feminist movement. Radical feminists asserted that it was not just legislative reforms that men and women needed, but rather that the very structures of society, which institutionalised patriarchy, needed to be radically altered (Douglas, 1990). This vision offered the possibility of ecstatic motion for all women. Yet, divisions between the two difference radical feminist camps, one of which asserted that men's and women's biological differences should not be seen as socially significant (Millett, 1970) and advocated lesbian separatism (Frye, 1978), and the other of which highlighted the importance of a shared culture among women (Redstockings, 1968), again acted as a deterrent. Indeed, since the two branches of radical feminism held dichotomous assumptions about a feminist futurity, the possibility of uniting women in collective movement across time and space was limited. Asexuality as a critical lens ${ }^{23}$ has the potential to both critique the liberatory rhetoric within twenty-first century feminism and reorient the work of radical feminists, so it is more inclusive of all women, including transgender individuals. ${ }^{24}$ Indeed, female (a)sexualities via Zorbitality expose the tiresome rhythms of feminisms past and present, and potentially offer a new rhythmic life, which can support women's collective movement, whilst viewing the term 'woman' itself as a dancing process (Riley, 1987).

In order to reconfigure the Rite, I argue that we need to look to the possibilities of Afro-diasporic rhythms as hybrid and transforming across space and time, highlighting collective ecstasy as the basis of human connection, whilst seeking to connect to the non-material world, through affective intensity. I will return to these possibilities in the next section, where I explore Martha's danced memory 
and her evocation of the uncreolised African body. However, to stage this, I will now go back to a scene of primary vulnerability, which is crucial to this cartography.

\subsection{Western colonisation and the devaluation of collective ecstasy}

As is commonly cited, Christopher Columbus reached what we know today as the Caribbean on 12 October 1492 . In total, he would engage in four voyages, which began an age of exploration, where Central and Latin America were founded and colonised by various conquistadores. Portuguese, French, English and Dutch colonisers carved up the remainder of these lands. Approximately one third of indigenous tribes had been wiped out by 1518 (Calvo Ospina, 1995, p. 5). In particular, the colonisers abhorred both the African slaves' and indigenous populations' love of music and began to use music as a form of control. For example, in 1614, the Bishop of Lima called for the destruction of all indigenous instruments (Slonimsky, 1945, p. 47). The colonisers brought Church and popular music with them, as well as courtly couple dances, such as the minuet and the quadrille, which would proliferate from the sixteenth to eighteenth centuries. These would fuse with African traditions, as at least 12 million slaves were brought to the new colonies from West Africa from the fifteenth to nineteenth centuries, to work primarily on sugar plantations (Segal, 1995, p. 4).

Significantly, couple dance did not feature in the African tradition, where collective circle dance to the beat of the drum was central. As Chasteen (2004, p. 13) asserts: '... something new and powerful happened when couple dancing met the liberation of the lower body to create the dance-of-two.' Yet, this process also 
devalued collective ecstasy, which Ehrenreich (2007, p. 9) refers to as 'self-loss in the rhythms and emotions of the group'25 and led to the naturalisation of the dyad in as the dominant configuration of Latin social dance, in such a way that it appeared to be natural (Kabir, 2013). ${ }^{26}$ As a challenge to this, my concept of Zorbitality features realigned erotic poles, from autoeroticism to polyamory, expanding from an ever-moving centre, where sexual pleasure is not seen as having its natural base in heterosexual dyadic formations (Van Anders, 2015). Neither is it necessarily genital, as Western theories of sexuality would have us believe. Rather, sexuality is a form of transformative movement across time and space. Just as Afro-diasporic rhythms have evolved over time, and within situated moments, through the experimentation of individual dancers and musicians, Zorbitality highlights the historical evolution of female (a)sexualities, and the possibility for new female subjectivities to emerge in situated moments of becoming. Zorbitality thus looks to an ethical futurity, where new possibilities are opened up for female (a)sexualities.

An interesting aspect of Ehrenreich's theory is that Western colonisers often associated dancing rituals with sexual consummation. Yet, these rituals often did not end in private or public sexual acts. For the colonisers, this was disturbing. How could one experience collective ecstasy if it did not lead to sex? The emergent concept of Zorbitality addresses this point, by suggesting that collective ecstasy can be seen as 'asexual,' in an ecstatic rather than a static sense. Collective ecstasy arguably connects us beyond differences in gender, sexuality, class and race, and allows us to connect in a deeper way with the nonmaterial world. Thus, it is a useful concept for addressing Braidotti's (2013) 
posthumanist call: Zorbitality transforms the negative energy held in the 'lack' of asexuality, into a positive and life-affirming concept. It involves a shifting energy and connectivity amongst people, whilst allowing one to transcend one's self. The Western world often cannot understand the love that may exist between members of a group, as opposed to the understanding of erotic love that exists between two human beings. This is because the concept of 'the Western world' emerged through a delinking of collective ecstasy from asexual dance. As I discussed in my analysis of The Rite of Spring, Stravinsky enacted this shift through mythopoesis, where an artificial mythology was created that viewed sexuality as a collective rite.

Whilst Ehrenreich's work is exemplary, she makes two problematic assumptions. Firstly, she assumes that not engaging in sexual activity is somehow less pleasurable than engaging in it, since one does not work towards reproduction and leaving a genetic trace:

Why should humans be rewarded so generously for moving bodies together in time? We are also pleasurably rewarded for sexual activity, and it is easy to figure out why: Individuals who fail to engage in sex, or heterosexual intercourse anyway, leave no genetic trace' (ibid, p. 26).

This stance denies the creative potential of movement for its own sake, and the fact that a 'genetic' trace can be made through one's movement both in present time and the life history one leaves. Ehrenreich's remarks also have undertones of what Rich (1980) called 'compulsory heterosexuality,' where sexualities misaligned with 'natural' reproduction are devalued. Equally, Ehrenreich sees erotic love for another as something that is innate and natural for all: "The capacity for collective joy is encoded into us almost as deeply as the capacity for 
the erotic love of one human for another' (Ehrenreich, 2007, p. 260). Yet, erotic love is not necessarily needed to reach a sense of transcendence.

In concluding this section, I wish to highlight how Western 'progress' has devalued the important tradition of collective ecstasy. Yet, Zorbitality as a resistant imaginary acts as a step towards addressing this issue. In the next section, I will draw on my second methodology: collective biography. I will firstly introduce the narrative of the African American anthropologist and dancer, Katherine Dunham, who experienced transformation during her fieldwork in the Francophone Caribbean, in tandem with that of Martha, a participant in collective biography work as part of my $\mathrm{PhD}$ research on female (a)sexualities. I will narrate Martha's transformative process, brought about by a danced moment, which evokes the specific figuration of West African Yoruba dance: solo dance within a collective. I argue that her memory evokes the memory of an uncreolised African body, as an act of ethical opening. Furthermore, her memory transfigures the sacrificial dance of 'the Chosen One,' thus transforming asexuality from a negative force into a positive dance of agency.

\section{Collective biography}

\subsection{Reconfiguring the Rite: The narratives of Katherine Dunham and Martha}

In 1936, the African American dancer and anthropologist, Katherine Dunham, first went to the Francophone Caribbean island of Haiti, having received the Rosenfeld Research Fellowship from the University of Chicago. As Dunham 
narrates in her memoir, Island Possessed (1969), her experiences in Haiti fundamentally changed her, as she was initiated into the danced West African religion, vaudun, and experienced the transformative power of Afro-diasporic rhythms. An awareness of this rhythmic life also fundamentally changed the way she viewed time, as she began to see it as a rounded rather than linear process, captured in her words: 'the present diffused in the roundness of time is the way I see time and events' (ibid, p. 46). This vision seems to reflect the 'circularity with volume' of Glissant's (1997, p. 32) work, which I highlighted in the introduction to this paper. This circularity looks beyond the 'arrowlike nomadism' (ibid, p. 18) of Western colonisers, to 'circular nomadism,' (ibid) where uprooting can be 'experienced as a search for the Other... rather than as an expansion of territory...'

Dunham (1969) experienced the process of circular nomadism firsthand. She initially felt unenthused, as she sought to reach the spirit of the serpent god, Damballa, yet could not reach the ecstasy she desired. She wished to return home many times but then realised that the research was actually transforming her. Through her initiation, she experienced a sense of empathy with African slaves who had been forced to cross the Atlantic in the previous centuries: 'There we lay, scarcely breathing, waiting, listening, senses alert, packed like sardines much as the slaves who crossed the Atlantic, motionless as though chained, some of us afraid' (ibid, p. 79). Furthermore, through the ecstatic danced rites she participated in during her vaudun initiation, she reached what could be described as Zorbitality. By internalising a collective spirit, personal ecstasy became the basis of a transformative power: 
We danced, not as people dance in the houngfor, with the stress of possession or the escapism of hypnosis or for catharsis, but as I imagine dance must have been executed when body and being were more united, when form and flow and personal ecstasy became an exaltation of a superior state of things, not necessarily a ritual to any one superior being (ibid, p. 109).

Dunham realised that the relationship between the imagined divinity and devotee's dance in the vaudun tradition reflected the symbology of the black peoples of the world. In particular, she noted the fluid movements of the yonvalou, a type of ecstatic movement that enabled Dunham to feel 'sublimely free because I was experiencing the ecstasy without being taken over, "mounted," or possessed' (ibid, p. 136). Dunham thus offered an alternative vision to the history of Western colonisation, which had been based on the forceful possession of other cultures and traditions. Rather, her vision highlighted how we can peacefully coexist whilst experiencing personal transformation through a culture's rhythmic life. ${ }^{27}$

Dunham's choreographic approach demonstrates the traces of this encounter and suggests a basis for Zorbitality . Firstly, her work draws on West African dancing traditions, which feature pelvic movement. In the Western world, these are often viewed as sexual. Yet, as Dunham (in Lloyd, 1949, p. 245) asserted: 'African movement is pelvic movement, natural and unself-conscious. It becomes erotic on the stages of civilization.' Secondly, Burt (2001, p. 80) rightly asserts that Dunham's work embodies 'a modernist ideal of freedom and liberation,' since she was an African American woman working within the confines of a conservative white society. Dunham enacted the possibilities of what Gilroy (1995) refers to as 'the Black Atlantic,' which calls for a radically reoriented view 
of modernity. This approach looks back to how enslaved people drew on Western ideologies, which 'then flowed into social movements of an anti-colonial and decidedly anti-capitalist type' (Gilroy, 2004, p. 44). Indeed, Dunham staged this when she drew on the resources of the Caribbean to create her own choreographic vision. She thoroughly internalised the spirit of collective ecstasy she experienced in her initiation into vaudun and this was key to her transformation. In Kabir's (2015b, p.18) words, she 'recovered the embodied memory of transcolonial rhythmic and kinetic collaborations arising from the Plantation to articulate her own sense of community and place within it.' In summary, Dunham's work offers three key ingredients, which offer groundwork for a Zorbital view of sexuality: strength and creative agency, new movement formations based on Afro-diasporic rhythms and a questioning of the established rules.

Dunham's work acts as an oblique entry point into this section, where I draw on my second methodology, collective biography (Davies and Gannon, 2006), as a methodology that explores the inter-relation of narratives, via memory and storytelling. I narrate the trajectory of Martha, a 34-year-old white middle-class able-bodied Irish woman who participated in the collective biography work I undertook as part of my PhD study on female (a)sexualities, as a nomadic counterpoint to Dunham's account. In line with the Braidottian lens of posthumanism, I wish to argue that Martha's memory, which features a dance that evokes the configuration of solo within a collective, does not celebrate the black African body but rather speaks to the memory of an uncreolised African body. Far from being a symbol of cultural appropriation, I argue that the 
uncreolised African body can be seen as a tool for transcending the limitations of human identity categories, and for connecting with human and non-human others. Her dance, in essence, speaks to the joy of life itself, where attention is drawn to the affective intensity of ecstatic shifts in one's subjectivity. Yet, these individual shifts can also encourage a more inclusive ethos at a societal level.

At the time of the research, Martha (34) was experiencing a process of transformation in both her personal and professional lives. For many years Martha had relationships with men and did not feel comfortable in them. She began to develop feelings for a woman at work and they slept together. She then realised that she really wanted to be with women, although she regretted losing her boyfriend, who was her 'best friend.' Although she did not continue the relationship with her work colleague, she met her girlfriend soon after, in 2009. Martha told me that she has been through an 'intense period' and that she is in 'the middle' of something right now. She also asserted that my research has been a 'trigger' for her transformation, after things 'rumbling under the surface' for months.

Soon after meeting her now girlfriend and leaving her physiotherapy job in London, Martha went travelling on her own in New Zealand and South-East Asia. Although she had worked as a physiotherapist before and had studied craniosacral therapy on the side, during her travels she realised that she wanted to make her psychotherapy practice the main focus of her career. Travelling allowed her the space to 'move on' from place to place, whilst granting her 'so much space' to think of what she wanted. This is a powerful evocation of the way 
travel can broaden the mind, and enable personal growth and transformation (see Frohlick, 2013). During her time in India, Martha took part in a vipassana meditation workshop, a collective spiritual practice that could be related to Dunham's initiation into vaudun in the Caribbean, and viscerally realised that she had deeply violated herself each time she had had a sexual relationship with a man.

Martha: I had this huge realisation that every time I had sex with a guy I was punishing myself, and I felt it really really physically, and it was so painful to realise that. (Collective biography, group 2, 08/02/2015)

It is not surprising that Martha uses the analogy of 'flow' to describe her current relationship with her girlfriend. In a similar way to Dunham's account, Martha's transformation thus has a lot to do with the transcendence of linear time, and an experiencing of affective intensity. Csikszentmihalyi (1992) asserts that a flow activity is one we did not expect to enjoy. Through engaging with it and setting ourselves challenges, we lose self-consciousness and begin to enjoy ourselves. True happiness emerges when we surpass all previous self-perceptions and reach a deep connection with others, human and non-human. This resonates with Martha's trajectory, as she had previously not expected to fall in love with women, or to experience the 'depth of connection' she immediately had with her girlfriend. In this way, she has found both a personal style of movement and a shared rhythm in her relationship.

Martha's trajectory has been building to the following dancing memory, which is the climax within the Zorbital flow of this paper. I will show how Martha's memory reconfigures the sacrificial dance of Stravinsky's (1913) Rite of Spring 
through an evocation of West African Yoruba dancing configurations, characterised by solo dance within a collective. Indeed, this specific configuration is vital for rethinking female (a)sexualities through Zorbitality, and indeed speaks to a posthuman concern with connecting to human and nonhuman others through the transcendence of identity categories.

As I described in the cartographies section, in Stravinsky's sacrificial dance, the young 'virgin' must dance herself to death. Yet, in contrast, Martha dances herself to life, through the propelling motion of the collective. By transforming in the process, Martha enables us to engage with the ethical possibilities of engaging in narrative work via the uncreolised African subject. I will engage with this via Mbembe's (2002) work on African self-writing, which encourages us to re-evaluate the role of sacrifice, so that new subjectivities can be enabled through 'self-styling' (ibid, p. 242). In the process, I will show how Martha's memory enables the full Zorbital process. She initially experiences vulnerability, yet transforms this into inner ecstasy and collective ecstatic motion in the process of the dance itself. Furthermore, she has internalised this collective spirit as a resistant imaginary.

\subsection{Defying Stravinsky's Sacrificial Dance: Evoking West African rites}

At no time during the dance does the Chosen Maiden show the personal terror that ought to fill her soul. She carries out a rite; she is absorbed by a social function, and without any sign of comprehension or of interpretation, she moves as dictated by the desires and impulses of a being vaster than herself, a monster filled with ignorance and appetites, with cruelty and darkness (Rivière, 1913, in Kirstein, 1975, p. 168). 
Through sacrifice, the African subject transforms his or her own subjectivity and produces something new - something that does not belong to the domain of a lost identity that must at all costs be found again, but rather something radically different, something open to change and whose theory and vocabulary remain to be invented (Mbembe, 2002, p. 269).

The opening quotes offer ways into a Zorbital analysis of Martha's memory. In the first quote, Rivière interprets the role of the Chosen One in the sacrificial dance of Stravinsky's ballet, The Rite of Spring (1913), based on his viewing of the work's premiere. Rivière sees the Chosen One as subsumed to a social function, dancing herself to death like an automaton. The Chosen One's asexuality as chosen 'virgin' is viewed negatively, and associated with 'ignorance' and 'darkness.' This paper has sought to challenge such a vision, by highlighting how women may engage in a collective ecstatic dance with regards to their (a)sexualities. In my analysis, I will therefore reconfigure Stravinsky's sacrificial dance, by asserting that Martha's memory demonstrates a dance to life.

In the second quote, Mbembe (2002) talks of African modes of self-writing and offers a vision of African subjectivity for a postcolonial age. He asserts that African subjectivity is always associated with the sacrifice of the African subject in the transatlantic slave trade. Yet, Mbembe highlights that new African subjectivities can be produced through the process of sacrifice itself. This assertion is vital for moving forward, since it denies that there is a lost African identity to be uncovered. Indeed, there is great power in the fact that African subjectivities can continually be reinvented, offering new forms of life. Mbembe's theorisations, I argue, offer a powerful metaphor for rethinking female (a)sexualities through Zorbitality, since they enable us to deconstruct the female 
'asexual' and to see her anew, in a sense of eternal movement. Furthermore, it appeals to a broader posthuman project, where we each harness different identities whilst seeking a closer connection with the non-material world.

I will now analyse Martha's journey from vulnerability to collective ecstatic motion at a weekend art workshop:

Martha: ... She took her clothes off, wrapped herself in a sarong. Went to the centre of the circle. Got on the floor, on her knees, in a ball. She was shaking, crying. She never felt more raw, more vulnerable. Like an open wound, exposed. The music started. Small movements at first and then she could let go, little by little. Never big movements but she stood. She let go of the sarong. The group would shout stop when they wanted to draw a pose. Just 30-60 seconds, however long you could stay still. Movement became a little more free, flowed a bit more but still terrifying, exposing. Then she turned, naked. No arm gestures, no covering herself, just her. Standing with her arms by her side, just her and then "STOP" echoed from the older women down one end of the room. She felt totally naked but totally present. Truly seen.

Afterwards the love she felt from the room was overwhelming. A flower from one, a look from another. Words of encouragement from all. At the end of the day one of the women asked if she could give her the picture she drew of the real her. Just her. Standing upright, showing herself, being nothing but herself.

It was beautiful.

And still is, framed in her bedroom. A reminder of what she can do. The true, honest, whole, vulnerable, brave, strong her. (Collective biography, group 2 , memory $4,08 / 06 / 2015$ )

Speaking of her memory, Martha said that she felt 'honest, vulnerable, painful and free.' This description is testament to the threefold Zorbital process, characterised by a journey from vulnerability to inner ecstasy and collective ecstatic motion. Prior to the scene in this memory, Martha experienced a lack of belief in her body. This emerged from a feeling that her creativity was 'totally blocked' and that she was unable to make a mark on the page, because of her 
'judgemental' voice. Thus, Martha evoked the mind/body split, which prevents one from reaching embodied experience, as highlighted by Gillies et al. (2005). Yet, she gradually learned how to 'connect' with the materials and make art, 'in her own way,' once she felt less hemmed in by other's expectations. Martha's body also felt stuck. She watched as other people danced naked, 'comfortable to be free in their bodies, free in their movement.' Equally, she was 'overwhelmed by her partner's naked beauty, her confidence.'

Following this came the sacrificial scene that Martha narrates in her memory, which enables us to engage with a reconfiguration of Stravinsky's sacrificial dance. Martha takes the courageous move to allow her body to make its mark within space. She feels completely overwhelmed as she chooses to enter the centre of the circle, wrapped in a sarong: 'She never felt more raw, more vulnerable. Like an open wound, exposed.' These are vivid images that demonstrate Martha's vulnerability, and superficially seem like the words of a sacrificial victim. Yet, as the music starts, her vulnerability begins to turn to inner ecstasy, as she makes 'small movements at first, and then she could let go, little by little.' Her movement becomes freer and freer. As she lets go of her sarong, her inner ecstasy transforms to collective ecstatic motion: 'Movement became a little more free, flowed a bit more but still terrifying, exposing.' She then turns, completely naked, with no arm gestures or anything covering her. This is 'just her.' At that moment, the older women at the end of the table shout 'STOP' to draw Martha's pose.

The combination of nakedness, movement and external acceptance creates an 
overall feeling of catharsis for Martha. She feels 'truly seen,' without being objectified. Significantly, she is living in the ecstatic present, rather than a painful past or fearful future: 'She felt totally naked but totally present.' Martha dances herself to life, offering herself to others in an ethical act, whilst experiencing the positivity of recognition: 'Afterwards the love she felt from the room was overwhelming.' One woman gave her the drawing she did, which Martha described as 'beautiful.' It now hangs framed on her wall, as a reminder of 'the true, honest, whole, vulnerable, brave, strong her.' Martha emerges as a peaceful warrior woman, rather than a sacrificial virgin.

The image of Martha dancing to life offers a powerful counter-narrative to the sacrificial dance of the young 'virgin' in Stravinsky's Rite of Spring, as her movement is generated from a place of vulnerability but is ultimately chosen by her, nobody else. Furthermore, Martha finally realises that her strength lies in allowing herself 'to be seen as vulnerable' by others. This awareness of vulnerability as a source of strength is a key difference between Martha's scene and Stravinsky's sacrificial dance. Furthermore, Stravinsky's dance ends with death, while Martha's is still reverberating in her everyday life.

Indeed, part of the reason why Martha's trajectory can be said to be a path of Zorbital transformation is that she draws on her body as a source of knowledge, much as Spry (2001) achieves in her work on performance ethnography. For example, during my research, Martha realised that she had never been recognised as an adult woman and experienced 'a rush of sadness, an eruption of tears, guttural crying from the belly - uncontrollable.' This vulnerability 
contrasted with her professional role, where she always spoke up for women of alternative sexualities within a patriarchal working environment. She began to realise that all the 'independent' things she had done to try and make her appear strong hid her vulnerabilities, namely that: 'I never ever let anyone help me' and 'I never let other people see me.' Her account of growing up in Catholic Ireland and the sense of somatic shame that this brought, meant that it took moving away from home to come to realisations about her sexuality, so deeply ingrained were the patriarchal structures in her home environment.

Yet, Martha has managed to transcend the sense of growing up in a 'shameful' body. Martha views the relationship between the body, identity and sexuality as situated and relational. She acknowledges how identities may shift over time and how the body itself is constantly 'evolving.' Central to her vision is 'following what it is that you need and want at that time.' Martha's account resonates with Zorbitality, for she highlights the needs of the vital body. Furthermore, her process reflects the trajectory of Latin American music, which has evolved through multiple cultural influences over time and in moments of experimentation (Madrid and Moore, 2013). These shifts in her subjectivity were experienced with affective intensity in this danced moment, which can be seen as an act of ethical opening.

I suggest that Martha's dance evokes the memory of the uncreolised African body, where collective movement configurations were at the heart of life, yet where a broader cosmos was encountered in the process of transformation. The Western colonisers naturalised the dyad and devalued the configuration of West 
African dance: solo dance within a collective, danced in a circle. I argue that Martha's dance invokes this dancing configuration and in the process transforms the role of the sacrificial subject. Her memory shows how an initial vulnerability can transform into inner ecstasy and collective ecstatic motion. Furthermore, she has carried the spirit of this dance into her personal life, since it now acts as a resistant imaginary. Therefore, her dance challenges a vision of the female 'asexual' as a subject of stasis and shows how vulnerability can create new configurations of identity, which have collective ecstatic motion at their core.

Martha's memory challenges the Western myth of origin, which asserts the racial unity of Africa and the existence of an 'asexual' subject. Her dance to life thus enables us to interrogate 'the imprisoning model of a history that is already shaped' (Mbembe, 2002, p. 258). The collective propels her to dance in a supportive and meaningful way, which suspends time and allows her to experience transformation in all its intensity. This resonates with Pavlicevic and Ansdell's (2009, p. 370) words:

They [West African dancers] are not simply responsive puppets, activated separately to move collectively. All collaborate socially, musically (the two are inseparable) in a highly fluid multisubjective event that moves towards the suspending of time (as chronos), space, culture, age, and social status.

Martha's memory, via Mbembe's (2002) work on African modes of self-writing, not only allows us to reflect on the African colonial subject but also the 'asexual' as an indigenous subject of twenty-first century Western sexuality discourses. Whilst I do not want to conflate the history of the transatlantic African slave trade with the status of female (a)sexualities in the twenty-first century, there are some lessons that can be learned. As Mbembe (ibid, pp. 240-242) asserts, the 
main issue arises in trying to integrate African subjectivity into one framework. He identifies two broad perspectives that are often used: (i) Marxist-inspired 'Afro-radicalism,' which draws on autonomy and resistance as the basis of an African identity and (ii) a nativist discourse, which reduces African identity to being part of the black race. As Mbembe highlights, the Marxist viewpoint does not allow Africans to represent themselves, through its focus on a revolutionary sacrifice. This politics 'required the total surrender of the individual to a utopian future and to the hope of a collective resurrection' (ibid, p. 251). In this way, politics becomes 'a sacrificial process' and history an 'economy of sorcery' (ibid, p. 252). The wounded subject becomes the desired subject. Meanwhile, in the nativist discourse, Africans are believed to have an authentic and distinct culture and are encouraged to look back to lost traditions. African people are seen as a collective black body, with the presumption of a unitary black African subject.

The problematic nature of both of these positions is reflected in approaches to asexuality as an identity category in the twenty-first century. There are two options. Either a person who does not desire genital sexual relationships is fitted into a neat category of asexuality, which is supposed to have a liberating and resistant collective function, and to allow the 'asexual' subject a place within history, or the 'asexual' is viewed as an indigenous subject to the Western norm of genital sexuality. The 'asexual' in this vision emerges as an inhuman subject without a history, since s/he must adopt a coloniser's discourse to be rendered intelligible. Indeed, as in the case of the 'African' subject, both of these conflicting perspectives are embodied in the same person. This allows little 
space for viewing female (a)sexualities through collective ecstatic motion. Yet, there are always possibilities.

Firstly, as Mbembe (ibid, p. 257) asserts, we need to 'deconstruct tradition,' so that Africa can be exposed as an invented concept in the Western imaginary. A similar approach should be applied to the 'asexual' as a figure that emerges from Western capitalist empires. Secondly, Mbembe highlights the importance of viewing Africa as 'an identity in formation' (ibid), much as this paper has sought to highlight how female (a)sexualities shift across time and within transformational moments. Mbembe (ibid, p. 258) ultimately concludes that this process would allow us to view the world as 'a vast network of affinities... the essential message here is that everyone can imagine and choose what makes him or her African.' Relating this to the study of female (a)sexualities through Zorbitality, I argue that we need to invent radical collective movement practices that break down the notion of the unitary subject, in the domains of race, class, sexual orientation, and beyond. Once we challenge the notion of a unitary subject, what comes to matter is how we choose to 'stylize' our lives (ibid, p. 273). Sexual identity is thus concerned with whatever movement configuration we choose to adopt. Zorbitality offers one such configuration: ecstatic solo motion within a collective. Yet, it goes beyond this by drawing attention to the remembered moment and to the intensity of life itself, which includes a broader cosmos of human and non-human others.

Mbembe's vision is conveyed in Martha's response to her memory, since she both challenges the myth of a unitary subject and experiences transformation in the 
moment. Furthermore, she extends Mbembe's musings by highlighting collective motion as the basis for her 'self-styling' (ibid, p. 242), which was characterised by:

Martha: ... letting go of that sense of moving in a certain way... 'cause it was all about finding your own movement, so you move in whatever way you want, em... it felt amazingly free to be given the space to just do that and to be allowed to do it as much or as little as I wanted, and to actually be able to then dance and move... in ways that I never thought I would ever do really, em, clothed or not clothed. You know, it was just, yeah, really... powerful. (Collective biography, group 2, 08/06/2015)

Martha's experience was all about finding her own unique style of movement: 'letting go of that sense of moving in a certain way.' Martha was searching for the origin of her movement, whilst deconstructing it and performing it anew. Indeed, what Martha experienced that day has had a knock-on effect in her personal and professional lives. She now stands up more than ever for women who do not relate to heteronormative structures. Equally, Martha and her girlfriend are considering having a child. This memory may well have set her desire in motion. Furthermore, the Zorbital research process that I instigated has empowered Martha to realise that she can be the agent of her own transformation:

Martha: ...It's been really powerful to actually answer these questions and to realise that I can choose it to be a different way as well. (Collective biography, group 2, 08/06/2015)

Martha's account is testament to the emergent concept of Zorbitality, where vulnerability is turned to strength through a realisation that one can continually construct oneself anew, by focusing on the intensity of the lived moment. She reaches a resistant imaginary through an internalisation of a collective spirit, thus completing the Zorbital process. Her memory embodies Mbembe's (ibid, p. 269) assertion that by 'putting to death innumerable sacrificial victims, the agent 
of the massacre also seeks to transcend and reinvent the self.' Indeed, by reaching a resistant imaginary, Martha shows us how we can transform the present and the past, whilst looking to a hopeful future, where we do our own dances in a propelling collective. Yet, this transformation is not propelled by the dance alone. A resistant imaginary emerges in finding a holding space for one's own style within a collective, whilst also channelling an open spirit to a space beyond the material world.

\section{$\underline{\text { 4. Conclusion }}$}

This paper has searched for myriad origins, deconstructed them and continuously performed them anew. It started from the viewpoint that various narratives interact in a continuous dancing process. Therefore, it has sought to draw together sociohistorical and biographical narratives of female (a)sexualities and to reconfigure them through the power of collective ecstatic motion. Indeed, this paper has contended that it is in the transformational moments of the everyday that female (a)sexualities are in flux and move to new horizons.

The paper engaged with two methodologies - Deleuzian feminist cartographies and collective biography - as well as the dance narratives of Stravinsky's (1913) ballet, The Rite of Spring, and West African Yoruba dance. In the process, it has sought to highlight the discourses that constrain women's ecstatic movement, whilst appealing to an enhanced sense of the collective via an engagement with the affective intensity of each moment. Furthermore, it has sought to show that by considering Latin American history as a collectively embodied global site of 
postcolonial trauma, we may begin to consider the relationship between the desired spontaneity of ecstasy and market demands. In the process, we may begin to see how women's collective movement may enable 'postcolonial happiness' (Kabir, 2016), through the celebration of personal movement styles within a set of shared rhythms. This addresses Hall's (2001 [1995], p. 291) aim for twenty-first century Caribbean identities: that we should not take 'old identities literally,' but rather, we should use 'the enormously rich and complex cultural heritages to which history has made them heir, as the different musics out of which a Caribbean sound might one day be produced.' In this way, we should view the categories of 'asexuality' and 'woman' as dancing processes and look to the resistant possibilities that may emerge from this.

As this paper has shown, by moving ecstatically together and writing about the experience of transformation from vulnerability to collective ecstasy, we can transform our histories. By displacing female (a)sexualities from their Western starting point, endless possibilities of repetition and transformation are opened up. Through internalising a collective ecstatic spirit, women can begin to thwart the patriarchal structures that have kept them in place, whilst creating an inclusive space for human and non-human others. Indeed, these are the possibilities that Zorbitality offers women for the future, as we continue dancing ourselves to a resistant imaginary. 


\section{Endnotes}

1 Throughout this paper, I draw on the word (a)sexualities, rather than 'asexuality' or 'asexualities.' The bracketing of the (a) seeks to destabilise asexuality as a categorical orientation that implies a 'lack' of sexual attraction and highlight that one may move in and out of asexuality throughout one's life. 2 The term 'libidinal economy' first surfaced in Lyotard's (1974) work, which highlighted the reciprocal relationship between politics and the libido.

${ }^{3}$ Asexuality and autoeroticism were viewed as separate categories in Johnson's (1977) chapter. In Johnson's synthesis, asexual women were those who did not want to engage in either partnered sexual relationships or masturbation.

Autoerotic women did not want to engage in partnered sex but masturbated. In the current definition of asexuality, autoeroticism is held within its grasp, as not being attracted to another person is considered to be the most significant factor in defining asexuality.

${ }_{4}^{4}$ The emergent concept is a term introduced by Deleuze and Guattari (1994 [1991]) in What Is Philosophy?, to designate a conceptual and analytical mode for examining new cultural phenomena.

${ }^{5}$ As noted by Guardiola-Rivera (2010, pp. 372-373), on 23 February 2010, the Cancún Declaration on the Unity of Latin America and the Caribbean was signed, thus uniting both sites in terms of economic and political goals. Therefore, I often cite 'Latin America' in this paper, since the Caribbean is held within its grasp.

${ }^{6}$ Zumba ${ }^{\circledR}$ Fitness was created by the Colombian choreographer, Alberto (Beto) Pérez, in the 1990s, and incorporates four core rhythms: Merengue, Salsa, Cumbia and Reggaeton. In recent years, it has adopted an increasing array of international genres.

7 This is also the basis of Ubuntu, an ethical philosophy that is prominent in South Africa, and which translates as 'I am because we are.' In other words, a person's dignity can be restored through 'others' co-participation in my dance' (Marx and Delport, 2017, p. 65).

8 Magical realism is a term that was first applied to Western Expressionist Art (see Roh, 1925). However, it reached its strongest manifestation as a Latin American literary genre. Magical realism emerged from Carpentier's (1995 [1949]) idea of lo real maravilloso, which highlighted how irony naturally exists within Latin American culture, with its innate blend of cultures and traditions, multi-faceted geography and fractured history, which seem fictional to an outsider. A further connection between Stravinsky's Rite and Latin America is evidenced in Carpentier's novel, La Consegración de la Primavera (1998 [1978]), in which Carpentier reconfigures Stravinsky's Rite through magical realism. As Chornik (2011) asserts, Carpentier chose both this work and method to represent innovative aesthetic ideas and the radical political convictions of the Cuban Revolution. The central character, Vera White, develops her own choreography for the Rite, which she seeks to stage with untrained Afro-Cuban dancers in Cuba. Vera also decides that the sacrifice of the Chosen One is deeply rooted in the present. I will draw on Vera's vision in Martha's memory.

${ }^{9}$ Many dancers have noted the physical endurance required for the role as 'Chosen' virgin. Lydia Sokolova, who danced the role in Massine's (1920) 
adaptation of Nijinsky's choreography, stated that: 'Whatever it did to the audience it nearly killed me' (Sokolova, 1960, p. 166).

10 This scene is titled Augurs of Spring.

${ }^{11}$ Ritual of Abduction.

12 Spring Rounds.

${ }^{13}$ Ritual of the Rival Tribes.

${ }_{14}$ Procession of the Sage.

15 Dance of the Earth.

${ }^{16}$ Mystic Circles of the Young Girls.

${ }^{17}$ Glorification of the Chosen One.

${ }^{18}$ Evocation of the Ancestors.

${ }^{19}$ Ritual Action of the Ancestors.

${ }^{20}$ Sacrificial Dance.

${ }^{21}$ Polyrhythm refers to two or more different rhythms being played simultaneously

22 Bausch's (1975) version was the only one that came close (see Hao Hoang Song, 2016).

23 Przybylo (2014, pp. 121-122) aptly refers to asexuality as 'an interdisciplinary method.'

${ }^{24}$ I reference here Greer's (2015) exclusionary remarks concerning male to female transgender individuals, which stated that they were 'not women.' 25 The ancient Greeks valued collective danced rituals, as manifested in the transformative spirit of Dionysus, the mythical god of collective ecstasy, who had a cult following approximately 2500 years ago. Dionysus was an androgynous and apparently 'asexual' figure, the god of ekstasis, who transported his followers beyond themselves (Storm, 1998). The cult of Dionysus serves to highlight that collective ecstasy was not necessarily of a sexual nature. With the rise of Christianity and modern warfare, the cult of Dionysus was gradually devalued and thus the suppression of collective danced traditions within the colonial encounter in the 'New' World can be seen as a completion of this process. ${ }^{26}$ Significantly, these were not explicitly couple dances, but were rather set dances. Couples danced in lines and moved to different partners. Partner hold was not used (see Manuel, 2009 for more on how these were creolised). The watershed moment occurred with the emergence of the waltz in nineteenthcentury Europe, which was the first strictly defined couple dance (see Scott, 2008). Significantly, it emerged at the very same moment as bourgeois capitalism. This marked a democratisation of the dance floor, which had the dyad at its core. The polka and mazurka added to this base. In Argentina, the most European-dominated Latin American country, the tango also emerged as a dance strictly for couples. The black influence in tango is often denied, but it is a fusion of European couple dance and African rhythm (see Dom Pedro's 2013 film, Tango Negro: The African Roots of Tango). For a comprehensive history of tango, see Savigliano (1995) and Farris Thompson (2006).

27 In 1941, Dunham choreographed Rites de Passage, a dance work that can be seen to reconfigure Stravinsky's (1913) Rite of Spring, by drawing on West African collective dance traditions. For more information on Dunham's conception, see Banes (1998, pp. 148-157). 


\section{Acknowledgements}

I wish to thank my PhD supervisors at King's College London, Professor Anna Reading and Professor Ananya Kabir for their continuing insights, and the ESRC for funding my PhD. I also wish to thank Professor Richard Giulianotti, Dr James Esson and other colleagues at Loughborough University for encouraging me to think in new ways about the role of sport in achieving sustainable development. I also wish to thank the trilogy of Zumba ${ }^{\circledR}$ teachers, Alejandra Loreto Quintana Alvárez, Charlotte Kabagwera and María Elena Venthoye Devora, who have inspired me on my journey to becoming a Zumba® Fitness instructor. I cherish their elegance, energy and strength. Finally, I wish to thank all the other Zumba® Fitness instructors worldwide, who welcome me as part of our global Zumba ${ }^{\circledR}$ community.

\section{Notes on contributor}

Aoife Sadlier completed her PhD in the Department of Culture, Media and Creative Industries, King's College London, in 2017. Her research explored the junctures and disjunctures between representations of female (a)sexualities and the lived experiences of various women across their life spans, and in particular examined the role that collective movement practices play in women's shifting (a)sexualities. Aoife currently works as a Research Associate on the 'New Development Frontiers? The Role of Youth, Sport and Cultural Interventions' project at Loughborough University, the United Kingdom, which is led by Professor Richard Giulianotti. She also teaches the global Latin dance fitness programme, Zumba ${ }^{\circledR}$ Fitness in various gyms and community settings. 


\section{$\underline{\text { References }}$}

AVEN (The Asexuality Visibility and Education Network) 2017 [online]. Available at: http://www.asexuality.org. [Accessed 29 December 2017].

Banes, S 1998, Dancing Women: Female Bodies On Stage, Routledge, London \& New York.

Banes, S 1998, 'Rites de Passage', in S Banes 1998, Dancing Women: Female Bodies On Stage, Routledge, London \& New York, pp. 148-157.

Benítez -Rojo, A 1996, The Repeating Island: The Caribbean and the Postmodern Perspective (Post-Contemporary Interventions), $2^{\text {nd }}$ ed. Translated from Spanish by J Maraniss, Duke University Press, Durham, NC \& London.

Berg, S 1988, Le Sacre du printemps: Seven Productions from Nijinsky to Martha Graham, UMI Research Press, Ann Arbor \& London.

Bogaert, AF 2004, 'Asexuality: Prevalence and Associated Factors in a National Probability Sample', The Journal of Sex Research, vol. 41 (3), pp 279-287.

Braidotti, R 2006, Transpositions: On Nomadic Ethics, Polity, Cambridge.

Braidotti, R 2012, Nomadic Theory: The Portable Rosi Braidotti, Columbia University Press, New York \& Chicester, West Sussex. 
Braidotti, R 2013, The Posthuman, Polity, Cambridge \& Malden, MA.

Burt, R 2001, 'Katherine Dunham's Rites de Passage: Censorship and Sexuality', in D Fischer-Hornung \& A Goeller (eds.), EmBODYing Liberation: The Black Body in American Dance, Verlag, Hamburg: LIT, pp. 79-89.

Butchart, A 1998, The Anatomy of Power: European constructions of the African Body, Zed Books, London.

Calvo Ospina, H 1995, Salsa!: Havana Beat, Bronx Beat. Translated from Spanish by N Caistor 1995, Latin American Bureau (Research and action), London \& New York.

Carpentier, A 1949, 'On the Marvelous Real in America', in L Parkinson Zamora \& WB Faris (eds.) 1995, Magical Realism: Theory, History, Community, Duke University Press, Durham, NC \& London, pp. 75-88.

Carpentier, A 1978, La Consegración de la primavera, Edición de Julio Rodríguez Puértolas, reissued 1998, Clásicos Castalia, Madrid.

Chasteen, JC 2004, National Rhythms, African Roots: The Deep History of Latin American Popular Dance, University of New Mexico Press, Albuquerque. 
Chornik, K 2011, Politics, Music and Irony in Alejo Carpentier's Novel La

Consegración de la primavera [online]. University of Manchester Research.

Available at:

https://www.research.manchester.ac.uk/portal/files/32469866/FULL_TEXT.PD

F [Accessed 13 July 2016].

Csikszentmihalyi, M 1992, Flow: The Psychology of Happiness, Rider Books, London.

Davies, B \& Gannon, S 2006, Doing Collective Biography (Conducting Educational Research, Open University Press, Maidenhead.

Deleuze, G \& Guattari, F 1980, A Thousand Plateaus: Capitalism and

Schizophrenia. Translated from French, with an introduction by B Massumi 2004, Continuum, London \& New York.

Deleuze, G \& Guattari, F 1991, What is Philosophy? Translated from French by G Burchell \& H. Tomlinson 1994, Verso, London \& New York.

Deloria, PJ 1998, Playing Indian, Yale University Press, New Haven \& London.

Denzin, NK 2014, Interpretive Autoethnography, $2^{\text {nd }}$ ed, Sage, Thousand Oaks, CA.

De Oliveira, SR and Still, J 1999, Brazilian Feminisms, University of Nottingham 
Press, Nottingham.

Douglas, CA 1990, Love and Politics: Radical Feminist and Lesbian Theories, ism Press, San Francisco, CA.

Dunham, K.1969, Island Possessed, The University of Chicago Press, Chicago \& London.

Ehrenreich, B 2007, Dancing In The Streets: A History of Collective Joy, Granta Books, London.

Emens, EF 2014, 'Compulsory Sexuality', Stanford Law Review, vol 66, pp. 303385.

Farris Thompson, R 2006, Tango: The Art History of Love, Vintage Books, New York.

Foucault, M 1976, The History of Sexuality: The Will to Knowledge, Volume I. Translated from French by R Hurley 1978 [Reprinted 1998], Penguin, London.

Fraleigh, SH 1987, Dance and the lived body: A Descriptive Aesthetics, University of Pittsburgh Press, Pittsburgh, PA. 
Freud, S 1954 [1897], 'Letter to Wilhelm Fliess' (No. 57: 24 January 1897), in M Bonaparte, A Freud \& E Kris (eds.) and E Mosbacher \& J Strachey (trans.), The Origins of Psycho-Analysis: Letters to Wilhelm Fliess; Drafts and Notes: 1887-1902, New Chiswick Press, London \& New York, pp. 188-191.

Freud, S. 2001 [1905], 'Three Essays on The Theory of Sexuality,' In J Strachey (trans.), The Standard Edition of the Complete Psychological Works of Sigmund Freud: A Case of Hysteria, Three Essays on Sexuality and Other Works (Volume Seven), Vintage, London, pp. 125-248.

Frohlick, S 2013, Sexuality, Women, and Tourism: Cross-border desires through contemporary travel (Contemporary Geographies of Leisure, Tourism and Mobility), Routledge, Abingdon \& New York.

Frye, M 1978, Some reflections on Separatism and Power (Reprinted 1981), Tea Rose Press, East Lansing, Michigan.

Garafola, L 1998, Diaghilev's Ballets Russes, Da Capo Press, Boston, MA.

Gill, R and Scharff, C (eds.) 2011, New Femininities: Postfeminism, Neoliberalism and Subjectivity, Palgrave Macmillan, London. 
Gillies, V, Harden, A, Johnson, K, Reavey, P, Strange, V, and Willig, C 2008, 'Painting Pictures of Embodied Experience: The Use of Non-linguistic Data in the Study of Embodiment', Qualitative Research in Psychology, vol. 2 (3), pp. 199-212.

Gilroy, P 1995, The Black Atlantic: Modernity and Double-Consciousness, Harvard University Press, Cambridge, MA.

Gilroy, P 2004, After Empire: Melancholia or Convivial Culture?, Routledge, Abingdon.

Giorgi, G 2012, 'Body', in R McKee Irwin \& M Szurmuk (eds.), Dictionary of Latin American Cultural Studies, University of Florida Press, Gainesville, Florida, pp. 34-37.

Glissant, E 1997, Poetics of Relation. Translated from French by B Wang, University of Michigan Press, Ann Arbor.

Goldberg, M 1986, 'She Who Is Possessed No Longer Exists Outside', Women and Performance, vol. 3 (1), pp. 17-27.

Greer, G 2015, Hadyn Ellis Lecture. Wales, University of Cardiff. 22 October 2015. Interviewed by Kirsty Wark [television]. BBC News, 24 October 2015. Available at: http://www.bbc.co.uk/news/uk-34625512 [Accessed 26 October 2016]. 
Guardiola-Rivera, 0 2010, What if Latin America Ruled the World?: How the South will take the North Through the $21^{\text {st }}$ Century, Bloomsbury, New York.

Hall, S 1995, 'Negotiating Caribbean Identities', in G Castle (ed.), Postcolonial Discourses: An Anthology, Blackwell Publishers, Oxford \& Malden, MA, pp. 280292.

Hoang Song, H 2016, Pina Bausch The Rite of Spring [video online]. Available at: https://www.youtube.com/watch?v=2w8ww_BfQBY [Accessed 28 November 2016].

Haug, F 1987, Female Sexualization: A Collective act of Memory. Translated from German by E Carter 1987, Verso, London \& New York.

Hill, P 2000, Stravinsky: The Rite of Spring, Cambridge University Press, Cambridge.

Hodson, M 1996, Nijinsky's Crime Against Grace: Reconstruction Score of the Original Choreography for Le Sacre du Printemps, Pendragon Press, Stuyvesant, New York.

Hollibaugh, A and Moraga C 1981, 'What We're Rollin' Around In Bed With: Sexual Silences', Heresies, vol. 3 (4), pp. 58-68. 
Irigaray, L 1987, Sex et parentés. Translated from French as Sexes and Genealogies by GC Gill 1993, Columbia University Press, New York.

Johnson, MT 1977, 'Asexual and Autoerotic Women: Two Invisible Groups', in HL Gochros \& JS Gochros (eds.), The Sexually Oppressed, Associated Press, New York, pp. 96-109.

Kabir, AJ 2013, 'The Dancing Couple in Black Atlantic Space,' in L Duran Almarza \& E. Delgado (eds.), Gendering the Black Atlantic, Routledge, London, pp. 133150.

Kabir, AJ 2015a, Zumba as a global phenomenon, unpublished manuscript.

Kabir, AJ 2015b, 'Plantation, Archive, Stage: Trans(post)colonial Intimations in Katherine Dunham's L'Ag'ya and Little Black Sambo', The Cambridge Journal of Postcolonial Literary Inquiry, vol. 2 (2), pp. 213-231.

Kabir, A 2016, 'On Postcolonial Happiness', in G Singh \& DD Kim (eds.), The Postcolonial World, Routledge, London \& New York, pp. 35-52.

Karras, RM 2005, Sexuality in Medieval Europe: Doing Unto Others, Routledge, New York. 
Keightley, E \& Pickering, M 2012, The Mnemonic Imagination: Remembering as Creative Practice, Palgrave Macmillan, Basingstoke \& New York.

Kramer, H \& Sprenger, J 1486, Malleus Maleficarum: The Hammer of Witchcraft. Edited by P Hughes and translated from German by M Summers 1968, The Folio Society, London.

Lefkowitz, MR \& Fant, MB 2005, Women's Life in Greece and Rome (3 ${ }^{\text {rd }}$ ed.), The John Hopkins University Press, Baltimore.

Levitas, R 2013, Utopia As Method: The Imaginary Reconstitution of Society, Palgrave Macmillan, Basingstoke \& New York.

Lloyd, M 1949, The Borzoi Book of Modern Dance, Dance Horizons, New York.

Lyotard, JF 1974, Libidinal Economy. Translated from French by IH Grant 1993, Athlone Press, London.

Macleod, C and Bhatia, S 2008, 'Postcolonialism and Psychology', in C Willig \& W Stainton-Rogers (eds.), The Sage Handbook of Qualitative Research in Psychology, Sage, London and Thousand Oaks, CA, pp. 576-589.

Madrid, AL and Moore, RD 2013, Danzón: Circum-Caribbean Dialogues in Music and Dance, Oxford University Press, Oxford \& New York. 
Manuel, P 2009, Creolizing Contradance in the Caribbean, Temple University Press, Philadelphia.

Marx, M and Delport, A 2017, '"I Am Because We Are" Dancing for Social Change!', Educational Research for Social Change, vol. 6 (1), pp. 56-71.

Massumi, B 2004, 'Notes on the Translation and Acknowledgements', in G Deleuze \& F Guattari 2004 [1980], A Thousand Plateaus: Capitalism and Schizophrenia, Continuum, London \& New York, pp. xvii-xx.

Mbembe, A 2002, 'African Modes of Self-Writing.' Translated from French by S Rendall, Public Culture, vol 14 (1), pp. 239-273.

Mbembe, A 2017, Critique of Black Reason. Translated from French by L Dubois, Duke University Press, Durham, NC \& London.

Mignolo, WD 2005, The Idea of Latin America, Blackwell, Boston, MA \& Oxford:

Milks, M 2014, 'Stunted Growth: Asexual Politics and the Rhetoric of Sexual Liberation', in KJ Cerankowski \& M Milks (eds.), Asexualities: Feminist and Queer Perspectives, Routledge, New York \& Abingdon, pp. 100-118.

Millett, K 1970, Sexual Politics, Doubleday, Garden City, New York. 
Pavlicevic, M \& Ansdell, G 2009, 'Between communicative musicality and collaborative musicing: A perspective from community music therapy', in S Malloch \& C Trevarthen (eds.) 2009, Communicative Musicality: Exploring The Basis of Human Companionship, Oxford University Press, Oxford \& New York, pp. $357-376$.

Parkinson Zamora, L. \& Faris, WB 1995, 'Introduction: Daiquiri Birds and Flaubertian Parrot(ie)s, in L Parkinson Zamora \& WB Faris (eds.), Magical Realism: Theory, History, Community, Duke University Press, Durham, NC \& London, pp. 1-14.

Przybylo, E 2014, 'Afterword: Some thoughts on asexuality as an interdisciplinary method', in M Carrigan, K Gupta \& TG Morrison (eds.), Asexuality and Sexual Normativity: An Anthology, Routledge, Abingdon \& New York, pp. 121-122.

Redstockings 1968, 'Redstockings Manifesto', in R Morgan (ed.) 1970, Sisterhood is Powerful, Random House, New York, pp. 533-536.

Rich, A 1980, 'Compulsory Heterosexuality and Lesbian Existence', Signs, vol. 5 (4), pp. 631-660.

Riley, D 1987, 'Does a Sex Have a History? “Women” and “Feminism”', New Formations, vol. 1 (1), pp. 35-45. 
Rivière, J 1913, 'From 'Le Sacre du Printemps' by Jacques Rivière: November 1913'. Translated from French by M Lassman, in L Kirstein 1975, Nijinsky Dancing, Knopf, New York, pp. 164-168.

Roh, F 1925, Nach-Expressionismus. Magischer Realismus. Probleme der neusten Europäischen Malerei, Klinkhardt und Biermann, Leipzig.

Savigliano, ME 1995, Tango And The Political Economy Of Passion: From Exoticism to Decolonization, Westview Press, Boulder, CO.

Segal, R 1995, The Black Diaspora: Five Centuries of the Black Experience Outside Africa, Farrar, Straus \& Giroux, New York.

Slonimsky, N 1945, Music of Latin America, Thomas Y. Crowell, New York. Sokolova, L 1960, Dancing for Diaghilev, John Murray, London.

Spry, T 2001, 'Performing Autoethnography: An Embodied Methodological Praxis', Qualitative Inquiry, vol. 7 (6), pp. 706-732.

Stacey, J 1999, 'Desperately Seeking Difference’, in M Shiach (ed.) 1999, Feminism and Cultural Studies, Oxford University Press, Oxford \& New York, pp. $259-274$. 
Stephenson, N \& Kippax, S 2008, 'Memory Work', in C Willig \& W Stainton-Rogers (eds.), The Sage Handbook of Qualitative Research in Psychology, Sage, London \& Thousand Oaks, CA, pp. 127-146.

Storm, W 1998, After Dionysus: A Theory of the Tragic, Cornell University Press, Ithaca, New York.

Stravinsky, I 1921 [1913], The Rite of Spring (Le Sacre du printemps): pictures from pagan Russia in two parts [score], Boosey and Hawkes, London.

Stravinsky, I 1975 [1935], An Autobiography (1903-1934), Calder and Boyars, London.

Tango Negro: The African Roots of Tango 2013 [Film], Directed by D Pedro, UMA Productions, USA.

Van Anders, SM 2015, 'Beyond Sexual Orientation: Integrating Gender/Sex and Diverse Sexualities via Sexual Configurations Theory', Archives of Sexual Behavior, vol. 44 (5), pp. 1177-1213.

Young, IM 1980, 'Throwing Like A Girl: A Phenomenology of Feminine Body Comportment, Motility and spatiality', Human Studies, vol. 3 (2), pp. 137-156. Republished in On Female Body Experience: "Throwing like a girl" and other essays 2005, Oxford University Press, Oxford, pp. 27-45. 